\title{
Determinants of Indonesian Gold Export to Singapore in 2006-2017
}

\author{
Regita Hikmatuz Zakia \\ Politeknik Statistika STIS \\ Jakarta, Indonesia \\ 15.8839@stis.ac.id
}

\author{
Siskarossa Ika Oktora \\ Politeknik Statistika STIS \\ Jakarta, Indonesia \\ siskarossa@stis.ac.id
}

\begin{abstract}
In Southeast Asia, Indonesia is the highest gold producer, in which Singapore has become the main destination for Indonesian gold exports since 2014. The volume of Indonesian gold exports to Singapore increased eightfold compared to 2013. At the same period, Singapore, which is not a gold producer is one of the top 10 countries with the highest gold export value in the world, while Indonesia's position is left behind Singapore. This study aims to analyze the variables that affect the volume of Indonesian gold exports to Singapore in 2006-2017. The analytical method used in this research is Autoregressive Distributed Lags (ARDL). The results showed that in the short term, there were significant effects of gold export volume a quarter prior, Indonesian gold production a year prior, Singapore's investments a year prior, and exchange rate. In the long term, the exchange rate and gold production were significantly affected by the gold export volume. The policy recommendation is government support in stimulating the establishment of national gold refining and manufacturing industry to increase profits by exporting value-added products through infrastructure and high technology support. The government should encourage the refining and gold manufacturing industries by implementing the Good and Service Tax elimination.
\end{abstract}

Keywords—gold export, international trade, ARDL

\section{INTRODUCTION}

Gold is one of the rare commodities that is frequently used in many sectors such as investment, jewelry, medicine, engineering, and aerospace because of its properties. As for today, gold demand has risen four times higher since 1970 [1]. On the other hand, gold production has tripled due to the exploration sites which grow more diverse and supported by better technology. This is supported by the fact that most of the gold production in 1970 was from the African continent, while in 2017 the top 10 countries with the highest gold production in the world were obtained nearly from all continents.

In Southeast Asia, Indonesia is the country with the highest volume of gold production, which is 154.5 tonnes in 2017. Around $86 \%$ of Indonesian gold is exported to other countries, such as Singapore, Hong Kong, Australia, and Thailand. The type of gold which is dominantly exported by Indonesia is unwrought nonmonetary gold which is not in powder form. This kind of gold is usually in ingot form, granule, chunk, and others. It is frequently processed as the inputs for jewelry, medals, decorations, nanotechnology, engineering tools, etc. However, Indonesian gold export to Singapore has risen from $14 \%$ in 2012 to $80 \%$ to 2017 . In the same time, Indonesia gold export to other destination countries has declined.

Singapore is one of the main destination countries for gold export, while at the same time Singapore is included in the list of top 10 countries with the highest gold export value in the world. The growth of Singapore gold export reached $855.4 \%$ since 2013, which shifted Singapore's rank based on the gold export value from 32 in 2012 to 8 in 2015. This condition is the opposite of Indonesia, which placed on rank 22 in 2012 then shifted to 21 in 2015 .

Export of commodity, mainly mining sector, is a very important aspect for a country because of its nonrenewable sources and rare discovery. Prior research on export mining in Tanzania shows that there was a growth of mining export reached $28.8 \%$ in 2008 [2]. According to this research, the mining sector has a large contribution to the income of a country, so that more in-depth studies to determine variables that affect the mining sector exports are needed. Some variables that might influence it are foreign investment, exchange rates, national income, and inflation. The results show that investment does not significantly influence Tanzania's export performance, but other variables are significantly influential. On the other hand, another research on Fiji export, which mainly focuses on gold, shows that there are some determinants of the country's export demand [3]. The research is using Autoregressive Distributed Lags (ARDL) as the tool to determine Fiji demand export. The results show that the destination country's income, export price index, and competitor export price index are significantly affecting the gold export demand.

The phenomenon of Singapore not having any sources of gold and be the main destination country for Indonesian gold export, while at the same time it becomes the country with the highest value of gold export is raising research questions such as what variables are influencing the export.

\section{MethodOLOGY}

\section{A. Data}

This research data is quarterly data with the period of 2006 to 2017. The used variables in this research are gold export volume from Indonesia to Singapore $(\mathrm{kg})$ which notated as $Y$ and obtained from Indonesia Central Bureau of Statistics, Indonesia gold production $(\mathrm{kg})$ which notated as Prod and obtained from Indonesia Central Bureau of Statistics, international gold price (US\$ $/ \mathrm{kg}$ ) which notated as $\mathrm{Pr}$ and obtained from World Gold Council, exchange rate 
(Rp/US\$) which notated as $E R$ and obtained from Bank Indonesia, and Singapore's investment to Indonesia (thousand US\$) which notated as FDI and obtained from Indonesia's Investment Coordinating Board. In this research, all variables in the equation will be transformed to their natural logarithm form symbolized by $l n$.

In this research, the independent variables are the gold export volume from Indonesia to Singapore in some period prior, gold production, international gold price, exchange rate, and Singapore's investment to Indonesia, while the dependent variable is the gold export volume from Indonesia to Singapore. The previous value of the gold export volume is included as an independent variable because it can act as the control variable which can detect the rigidity of export [4]. It is because the previous value of the gold export volume is related to the supply-demand of the commodity in the destination country of export. If the quantity of gold exported in the previous period were high, then the supply of gold in that destination country would also rise. Therefore, the demand for gold from the destination country will be affected depending on the circumstances on the market.

Hecksher-Ohlin international trade theory stated that a country would export any commodity that can be produced abundantly in the country. Based on this theory, gold production should be included as one of the independent variables because gold is produced abundantly in Indonesia. Therefore, it may affect the gold export volume.

Based on the supply-demand theory, the quantity of commodity demand and its price has a negative relationship, which means that if the price rises then the quantity will decrease [5]. It is very suitable for elastic goods, such as gold. In terms of the international market, if the international gold price is higher than the domestic gold price, then a country will tend to export their gold overseas. This is encouraged by the higher profit that it will receive when exporting to overseas.

Moreover, the economic condition may also influence how international trade performs [6]. When depreciation hits domestic currency, then the price of goods in domestic market will be higher than the price of goods in the international market. This encourages domestic producers to export their goods to international market, which means that exchange rates will affect how many particular goods, such as gold, is exported to international market. Foreign investment is one of the main drivers of international trade [7]. Foreign investment that enters a country is expected to increase the productivity of the country economy, which can encourage export escalation.

Based on the HS code, there are three types of Indonesian gold export, HS code of 710811 for unwrought nonmonetary gold in powder form, HS code of 710812 for unwrought nonmonetary gold in the form of other than powder, and HS code of 710813 for semi-manufactured nonmonetary gold. This research focused on gold with HS code of 710812 because $96.86 \%$ of Indonesian gold export is in this type of gold.

\section{B. Autoregressive Distributed Lags (ARDL) Model}

Autoregressive Distributed Lag (ARDL) is one of the dynamic models with lagged dependent variable and lagged independent variables in the equation [8]. Also, ARDL can be the solution to determine the long-term relationship in nonstationary variables [9]. Besides, ARDL is utilized to determine the cointegration process when the variables are not stationary in the same ordo. In this condition, ARDL will generate realistic and efficient estimation [10]. In this research, ARDL is used to determine how independent variables affect dependent variables when the data is structured in a time-series format and is not stationary in the same order. Also, ARDL accommodates the lag of the dependent variable as one of the independent variables in the equation.

The general ARDL equation based on Greene (2003) is:

$$
\begin{aligned}
& y_{t}=\alpha_{0}+\sum_{i=1}^{p} \Psi_{i} y_{t-i}+\sum_{j=1}^{q} \beta_{j} x_{t-j}+\varepsilon_{\mathrm{t}} \\
& \alpha_{0}: \text { Intercept } \\
& \psi_{\mathrm{i}}: \text { Coefficient of lagged dependent variable, } \mathrm{i}=1, \ldots, \mathrm{p} \\
& \beta_{\mathrm{j}}: \text { Coefficient of lagged independent variables, } \mathrm{j}=1, \ldots, \mathrm{q} \\
& \mathrm{p}: \text { number of lag for the dependent variable } \\
& \mathrm{q}: \text { number of lag for the independent variable } \\
& \varepsilon_{\mathrm{t}}: \text { error term }
\end{aligned}
$$

In building the ARDL model, the steps required are written as follows:

\section{1) Stationarity testing}

Stationarity test is conducted by Augmented DickeyFuller (ADF) test. When all variables are stationary in level or first difference form, then the ARDL model can be built (Pesaran and Shin, 1998).

\section{2) Optimum lag selection and building ARDL model}

To build the ARDL model, the maximum lag length is determined based on the structure of data. In this research, the maximum lag length chosen is 4 , because the data is structured in quarterly. With the maximum lag length of 4 , then any influence up to a year prior will be able to capture in the model. After choosing the maximum lag length, all models with different combinations of lag length will be compared based on their criterion values, such as Akaike Information Criterion (AIC), Schwarz Criterion (SC), dan Hannah Quinn Criterion (HQ). The best ARDL model is the model with the lowest criterion value.

\section{3) Classical assumptions testing, partial test, and simultaneous test}

Classical assumptions testing in the ARDL model are the normality test, homoscedasticity test, nonmulticollinearity test, and non-autocorrelation test. Jarque-Bera test is used to test whether the error of the ARDL model is in normal distribution form. BreuschPagan-Godfrey test is used to test whether the error of the ARDL model has the same variance (homoscedastic). Breusch-Pagan (LM test) is used to test whether the error of the ARDL model is correlated within another. While VIF is to determine whether independent variables are correlated between each other. Also, a partial test is conducted by t-test to determine whether a specific variable is significantly affecting the dependent variable. 
While the simultaneous test is conducted by F-test to determine whether there is at least one independent variable significantly affect the dependent variable.

\section{4) Bound Testing}

Bound testing is a test to determine whether variables in the ARDL model is cointegrated. This test is utilizing F-Wald test approach [11]. When the F statistic obtained from the test is greater than I (1) Bound, then the decision is to reject the null hypothesis [12]. It means that there is cointegration in the ARDL model; thus, the long-run model can also be generated.

\section{5) Long-run model estimation}

Long-run model is a model that will show how independent variables affect the dependent variable in the long-run. The general long-run model is written as follows:

$$
y_{t}=\alpha_{l r}+\sum_{j=1}^{k} \delta x_{j}, t+\varepsilon_{\mathrm{t}}
$$

$$
\begin{aligned}
& \alpha_{l r}: \text { Intercept of long-run model } \\
& \delta_{j}: \text { Coefficient of the long-run model of } x_{j, t}
\end{aligned}
$$

\section{RESUlTS}

\section{A. Indonesian Gold Export to Singapore}

Indonesian gold export volume to Singapore is fluctuating from 2006 to 2017 . The first quarter of 2009 , gold export volume rose five times compared to the last quarter of 2008. It is due to a global recession in 2008. The demand for gold is rose by $182 \%$ in the last quarter of 2008 , which encourage the rise of gold export volume in the first quarter of 2009 because Singapore is the most strategic country for international trade [1].

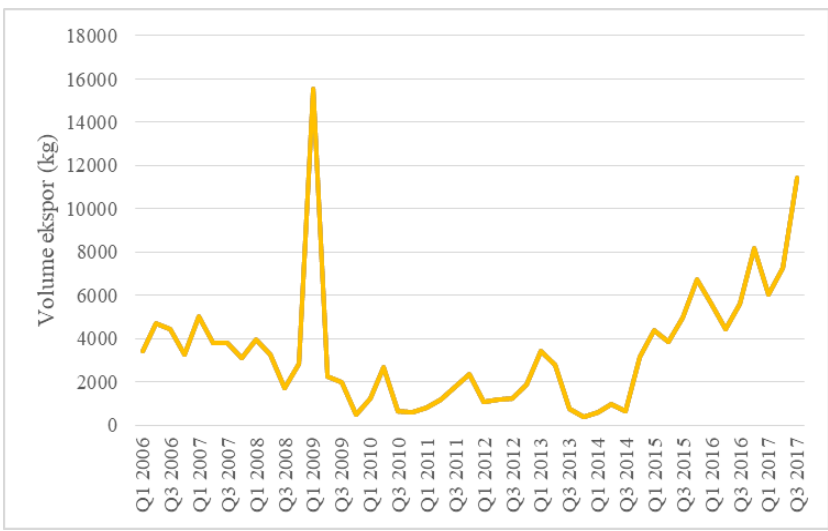

Fig. 1. General description of gold export volume to Singapore

Also, Singapore had built several smelter and refineries of gold. One of them is Metalor Singapore, which is the biggest refineries in Asia. Besides, Singapore also built several gold vaults such as Singapore Freeport and Silver Bullion's The Safe House, which are very sophisticated. This encourages people to save their gold at those gold vaults. In addition, Singapore is geographically strategic, so it will be easier to access across many countries. Since 2014, the Indonesian gold export volume to Singapore has increased. This is due to the elimination of Goods and Service (GST) Tax in Singapore, specifically for gold, silver, and platinum. The elimination of GST Tax and some new smelters and refineries in Singapore could encourage the ecosystem of Singapore's gold market.

At previous period, the main destination country of gold export for Indonesia is Hong Kong, but since 2014 to 2017 Singapore has become the first rank replacing Hong Kong as the main destination country of gold export. Since 2014 the percentage of gold export volume to Singapore increased significantly from $14 \%$ in 2012 to $81 \%$ in 2016 . In the same period, the percentage of gold export volume to other destination countries has declined.

\section{B. ARDL Model}

\section{1) Stationarity testing}

Stationarity test is conducted by the ADF test considering intercept and trend in each variable. Stationarity test is conducted on the level and first difference.

TABLE I. STATIONARITY TEST

\begin{tabular}{|c|l|c|c|}
\hline No. & Variable & $\begin{array}{c}\text { p-value on } \\
\text { level }\end{array}$ & $\begin{array}{c}\text { p-value on first } \\
\text { difference }\end{array}$ \\
\hline 1. & $\ln \mathrm{Y}$ & 0.1128 & $0.0000^{*}$ \\
\hline 2. & $\ln \mathrm{Pr}$ & 0.1131 & $0.0000^{*}$ \\
\hline 3. & $\operatorname{lnProd}$ & 0.0611 & $0.0000^{*}$ \\
\hline 4. & $\operatorname{lnFDI}$ & 0.0843 & $0.0000^{*}$ \\
\hline 5. & $\ln \mathrm{ER}$ & 0.7937 & $0.0004^{*}$ \\
\hline
\end{tabular}

Based on Table 1, with alpha $5 \%$ all of the variables are stationary in first difference form.

\section{2) Optimum lag selection and building ARDL model}

ARDL model shows how volume export in the past, Singapore investment, gold production, international gold price, and exchange rate influence gold export volume in the short-run. The criterion to choose the best model is AIC because it performed better when the observation size is 5060 [13]. The best ARDL model based on AIC is ARDL $(1,4,0,4,0)$. This model has met every classical assumption, such as the normality test, homoscedasticity test, nonautocorrelation test, and non-multicollinearity test.

Based on simultaneous test on every independent variable, the F-statistic of 6.0804 with p-value of 0.000 shows that with the level of significance $5 \%$ there is at least one variable significantly influences the gold export volume of Indonesia to Singapore. Also, the adjusted R-squared of 0.7315 means that all dependent variables in the model determine $73.15 \%$ of the variation in gold volume export. This high value of adjusted R-squared means that gold export volume can be explained well by all dependent variables, including the lag variables. 
The ARDL model in this research is as follows:

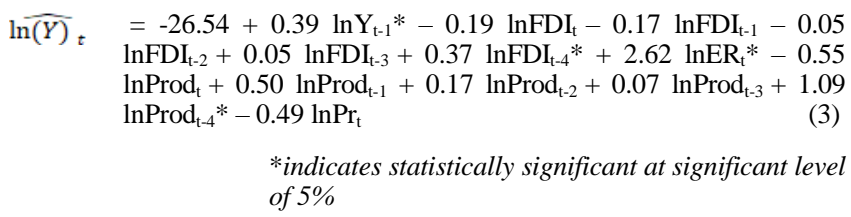

Based on partial test, the variables that significantly affects Indonesian gold export volume to Singapore are Singapore's investment one year prior, gold production one year prior, gold export volume one quarter prior, and exchange rate.

Coefficient of gold export volume one-quarter prior is 0.39 , which means that the rise of $1 \%$ gold export volume in the last quarter will rise the gold export volume in the current quarter by $0.39 \%$. This is aligned with previous research regarding the effect of lagged export volume to the current export volume [14]. The findings show that there is a significant effect of lagged volume export to current volume export.

Singapore's investment to Indonesia one year prior has the coefficient of 0.37 which means that the rise of Singapore's investment one year prior will rise gold export volume to Singapore in the current quarter by $0.30 \%$. This is aligned to previous research regarding the effect of foreign investment to export volume in Cambodia in 1985 to 2016 [14]. This research found that there is a significant effect of foreign investment to export volume. It is also stated that export-oriented investment would increase the export volume, while investment which is focused on the domestic market will decrease export volume.

Coefficient of the exchange rate (rupiahs to US dollars) of 2.26 means that the rise of $1 \%$ exchange rate will raise the gold export volume by $2.26 \%$ in the short-run. This is aligned with previous research that determines the effect of the exchange rate to export volume in South Africa [15]. This research found that there is a significant effect of the exchange rate to export volume in South Africa in the shortrun. Also, another previous research found that the exchange rate affects export volume significantly in Zambia [16].

Coefficient of gold production one year prior is 1.09 which means that the rise of gold production by $1 \%$ will increase the rise of gold export volume by $1.09 \%$ in the short-run. This is aligned with previous research regarding the export volume in Zimbabwe [17]. This research found that there is a significant effect of production in 1 year before the current export volume in Zimbabwe. This is because the product can be saved as the stock.

\section{3) Bound test}

Bound test generated from this model has the F-statistic of 3.995. The Bound value with a significance level of $5 \%$ for $\mathrm{I}(0)$ is 2.85 and 3.905 for $\mathrm{I}(1)$. The f-statistic value that is higher than $I(0)$ and $I(1)$ Bound value means that there is cointegration in the model. Therefore, the long-run model can also be obtained in this research.

\section{4) Long-run model}

The long-run model is written as follows:

$$
\begin{aligned}
\widehat{\ln (Y)_{t}} & =-43.6+2.14 \ln \operatorname{Prod}_{\mathrm{t}} *-0.81 \ln \mathrm{Pr}_{\mathrm{t}}+4.30 \operatorname{lnER}_{\mathrm{t}}^{*} \\
& -0.06 \operatorname{lnFDI} \mathrm{t}
\end{aligned}
$$

*indicates statistical significance at the level of 5\%

Based on the equation (3), gold production and exchange rate significantly affecting gold export volume from Indonesia to Singapore in the long-run. Coefficient of 2.14 for gold production means that if Indonesia had the time to adjust to the economic equilibrium, then the rise of gold production by $1 \%$ will raise the gold export volume by $2.14 \%$. This is supported by previous research findings that production affects export volume in Zimbabwe in the longrun [17].

On the other hand, exchange rate coefficient of 4.30 shows that if Indonesia had the time to adjust to economic equilibrium, then depreciation of rupiah value to US dollars of $1 \%$ will increase gold export volume by $4.30 \%$. This is supported previous research finding which shows that the depreciation of domestic currency will give significant effect to the export volume in the long-run [16].

The presence of cointegration which proved by the Bound test means that error correction term in the ARDL model can be interpreted. The error correction term is generated from the error correction model in the ARDL. The error correction term of this model is -0.6087 , which means that $60.87 \%$ deviance in the short-run will be corrected in the next quarter.

\section{CONCLUSION}

The conclusions of this research are as follows: First, gold export volume is generally increased since 2014. Based on the data, there might be an influence of gold export volume in the past and other economic variables to the current gold export volume. ARDL is used because the data is structured in a time-series format and is not stationary in the same order, and use the lag of gold export volume as one of the independent variables in the equation.

By using ARDL, it is shown that in the short-run there is a significant effect of the exchange rate, gold export volume 1 quarter prior, Singapore's investment one year prior, and gold production one year prior. While, in the long-run, there is a significant effect of the exchange rate and gold production.

Based on the conclusion, there are some policy recommendations such as increasing government support to stimulate gold refineries and smelter industry because the majority of gold that is produced by Indonesia is not in its wrought form. Also, implementing the elimination of GST Tax could encourage the industry of gold smelter and refineries. Besides, government could implement the policy to prevent excessive gold exploitation, because majority of gold export of Indonesia is in its unwrought form. 


\section{REFERENCES}

[1] World Gold Council, "Gold Demand Trends Full Year 2008", Accessed on March $19^{\text {th }} 2019$ from https://www.gold.org/goldhub/research/gold-demand-trends/golddemandtrends-full-year-2008

[2] R. Johansein and S. Aneth, "Econometric Analysis of FDI in the Mining Sector to Tanzania's Export Capacity", Knowledge Horizons Economics, Faculty of Finance, Banking and Accountancy Bucharest. vol. 4(1-2), 25-37, 2012.

[3] S. Narayan and P.K. Narayan, "Determinants Of Demand For Fiji's Exports: An Empirical Investigation”, in The Developing Economics, vol 42, issue 1, March 2007.

[4] Rahardja, Sjamsu. "Big Dragon, Little Dragons: China's Challenge to the Machinery Exports of Southeast Asia”. Policy Research Working Paper; No. 4297, 2007. World Bank, Washington.

[5] S. Sadono, Makroekonomi: Teori Pengantar, Third Edition, Rajagrafindo Persada: Jakarta, 2009

[6] Mankiw, N. Gregory, Macroeconomics (Seventh edition). New York: Worth.

[7] D. Salvatore, International Economics, New Jersey, GGS Book Services, 2007.

[8] G. Damodar, Basic Econometrics (Fourth ed.), McGraw Hill: CA 2004.
[9] Pesaran, M. H. and Shin, Y. "An autoregressive Distributed-lag Modelling Approach to Cointegration Analysis. Econometric Society Monographs", 31:371-413, 1998.

[10] E. Nkoro and Uko, A. K, “Autoregressive Distributed Lag (ARDL) cointegration technique: Application and Interpretation", Journal of Statistical and Econometric Methods, vol.5, no.4, 2016, 63-91, 2016.

[11] M. Pesaran, Y. Shin and R. Smith, "Bounds Testing Approaches to The Analysis of Level Relationships", Journal of Applied Econometrics, 16(3):289-326, 2001.

[12] P.K Narayan, "The Saving and Investment Nexus for China: Evidence from Cointegration Tests", Applied Economics, 37, (2005), 19791990.

[13] Venus Khim, Sen Liew. "Disaggregated Energy Consumption and Sectoral Outputs in Thailand: ARDL Bound Testing Approach". Journal of Management Sciences. Vol. 3(1) 39-51, 2016.

[14] Dube, A.K., Ozkan B. "Analyzing the Export Performance of the Horticultural Subsector in Ethiopia: ARDL Bound Test Cointegration Analysis". Horticulturae. 4(4), 34, 2018.

[15] M. Ngondo and H. Khobai. "The impact of exchange rate on exports in South Africa," Working Papers 1809, Department of Economics, Nelson Mandela University, revised Mar 2018

[16] J. Mabeta and H. Bett, "Growth of Tobacco Exports in Zambia: An ARDL Approach". Journal of Economics and Sustainable Development. Vol. 6, No.18, 2015.

[17] M. Edwin, "Estimation of the aggregate agricultural supply response in Zimbabwe: The ARDL approach to cointegration", School of Economics, University of Cape Town, 2008 